\section{Herbert E. Alexander}

Herbert E. Alexander, distinguished professor emeritus of political science at the University of Southern California (USC), died of cancer on April 3, 2008, at the age of 80 . For 40 years, Alexander was director of the Citizens' Research Foundation (CRF), a nonprofit organization devoted exclusively to studying and informing the public about political finance. CRF was founded in 1958, the same year Alexander received his Ph.D. in political science from Yale. After 20 years as an independent organization based in Princeton, New Jersey, CRF moved to and became part of USC in 1978, where it stayed until Alexander's retirement in 1998.

In 1961-1962, Alexander took a leave from CRF to serve as executive director of the President's Commission on Campaign Costs under President John F. Kennedy and served subsequently as consultant to President Kennedy on legislation based on the commission's report. This was the first of many times he was a consultant to governments at all levels in the U.S. and abroad. In 1996, he was awarded the Samuel J. Eldersveld Career Achievement Award by the Political Organizations and Parties Section of the American Political Science Association, in honor of his lifetime contributions to the field. In 2004, he received the Annual Award from the Council of Government Ethics Laws-the professional organization for campaign finance and government ethics officials in the U.S. and Canada.

After retirement, Alexander moved to Silver Spring, Maryland, where he remained professionally active. He was predeceased by his wife Nancy G. Alexander and granddaughter Victoria Alexander. He is survived by three sons and their wives, Michael (Sandra) of East Windsor, New Jersey; Andrew (Lisa) of Toronto, Canada; and Kenneth (Susan) of Olney, Maryland; five grandchildren; and his companion, Barbara B. Seidel.

\section{Professional Mark}

Herb Alexander was often described as the "dean" of political finance scholarship in the United States and internationally. That description barely does him justice. For years he worked virtually alone. He was not only the dean but almost the whole faculty defining the field in which many of us now labor.
Many political scientists know Alexander's signature books - the quadrennial series that began with Financing the 1960 Election, and continued with Herb as principal author through Financing the 1992 Election. As important as these books are, they represent a small part of Alexander's full output. Shortly before he died, Herb contributed a library of all of his published writings to The Campaign Finance Institute, a research institute affiliated with The George Washington University that I have been privileged to run. As we took in the library, it quickly became clear to me that even though I had consulted and owned much of his work for more than 30 years, I in fact knew less than half of the whole. The full collection contained 20 books and more than 375 articles, papers, speeches, and other finished writings.

The quadrennial Financing series built on painstaking methods he learned from his teacher, Alexander Heard, and from the work of Louise Overacker, whose original index cards of campaign finance data were later stored in the CRF offices. Much of the research was carried out before effective disclosure laws. According to CRF's longtime assistant director, Gloria Cornette: "Dr. Alexander had to rely on the extensive list of contacts he developed as well as on his own persistence to uncover the information he needed to generate his studies. He attended every Democratic and Republican National Convention from 1960 to 1992 , where he met with political party officials and campaign operatives as well as political fund raisers and donors, from whom he drew the information that informed his narratives." What is most remarkable is that he got these people to give not merely generalities, but details with numbers that allow meaningful comparisons across campaigns and years. His information-gathering methods fell into disuse in the years after computerized disclosure. That is unfortunate, because we will need them again if (as expected) there is an increase in electionrelated spending by organizations that fall outside the law's reporting requirements.

Much of Herb's additional work can best be described as policy analysis, looking at the effects of federal, state, and local campaign finance laws in the U.S. and other countries on the institutions of democracy. The analyses were often coupled with recommendations.
The recommendations shifted in their specifics over the years as laws changed, but maintained a fundamental consistency on the big issues. In Financing the 1960 Election, Herb wrote about the value of encouraging "a vast expansion in the numbers of small contributors. This does not exclude a policy of partial subsidies," such as a tax credit. A sound policy, he argued, should "recognize that political contributions constitute a reputable form of public service, and would be in accord with the principle that every public spirited citizen who has a party preference should contribute financially, in moderate amounts, to the political party of his choice."

Two decades later, the same principles led him to a position that maintains currency in the political arena. "Rethinking reform," he wrote in a 1984 volume I edited, "leads to the ideal concept of floors without ceilings: a system that would provide candidates with partial public funding but not expenditure limits." He supported limits on contributions to candidates-Herb was not a libertarian, though he was concerned that the limits were too low for seed money. Yet he also favored removing the limits on contributions to the political parties, as well as the limits on party expenditures. (See his contribution to Money and Politics in the United States: Financing Elections in the 1980s.) Consistent with these positions, Herb two decades later opposed the McCain-Feingold law's ban on political party soft money. "Elections are improved by well-financed candidates and parties able to wage competitive campaigns, not by stifling political dialogue," he wrote in the Election Law Journal in 2003.

In all cases, whatever the details, Herb was concerned simultaneously about participation, transparency, and corruption. This led him to disagree with many of his colleagues on specific issues, but such disagreements were inevitable. It is a lot easier to resolve balancing problems if you are willing to satisfy only two (any two) of the three goals he juggled. The hard policy choices come when you try to keep all three in play at once. He did so, and the rest of us in the field learned from that effort, even if some of us have come to different conclusions on some particulars.

Alexander's comparative work is also worthy of note. From 1973 to 1994 he was chair of the Research Committee on Political Finance and Political Corruption 
of the International Political Science Association. He edited two volumes of comparative political finance during those years, and served as a frequent election observer and as a consultant to the U.S. Agency for International Development. In 2001, 23 scholars contributed to Foundations for Democracy: Approaches to Comparative Political Finance a series of essays written in his honor. In the editor's preface to that volume, Karl-Heinz Nassmacher wrote that Alexander "has been the most eminent and prolific author on political finance in the U.S. for no less than four decades and the cornerstone of international scholarship in the field since the 1970s." Those sentiments were echoed shortly after his death by political scientists Rei Shiratori of Japan, Michael PintoDuschinsky of Great Britain, and Menachem Hofnung of Israel, as well as by many others within the U.S.

In recognition of Herbert Alexander's contributions to the field, The Campaign Finance Institute will host a reception in his honor at the 2008 annual meeting of American Political Science Association. CFI will also make his library available to scholars and hopes to post many of his writings on a dedicated page on the CFI web site.

\section{Eulogy by Kent Cooper}

We close this tribute by reproducing extended excerpts from the eulogy delivered at Herb's funeral by Kent Cooper, who was for 20 years chief of the Public Records division at the Federal Election Commission and later a co-founder of Political Money Line:

"I have been asked to say a few words about Herb's professional career. Needless to say I am at a disadvantage. It is hard to say a few words about someone who wrote over 20 books and produced more than 375 articles, speeches, and testimony during his 50-year professional career.

"In fact he wrote so much, he crafted an entirely new field of study - that of political finance. When I first met Herb in 1973 I was already benefiting from the field he helped create. For the next 35 years I worked in that field and enjoyed his friendship, his counsel, and his valuable analysis of money in politics.

"But it was not easy for him; it took a lot of painstakingly methodical and tedious work. From working as a student with Alexander Heard, to his going over the $3 \times 5$ contributor cards complied by Louise Overacker, he learned to dig for details and document the trends and patterns of financing elections. Early on he established a set of standards and measurements to chart the role of money in politics consistently.

"Even the method and topic of his Yale doctoral dissertation, 'The Role of the Volunteer Political Fund Raiser: A Case Study in New York in 1952,' is just as relevant today, although it might be called 'New York bundling.' It named names and brought life to black and white financial figures.

"Herb's role as executive director of President John F. Kennedy's Commission on Campaign Costs provided a unique opportunity to meet and hear the top political leadership of the national political system. The Commission worked for six months and produced a core report some of whose key recommendations were adopted over time ...

"From then on Herb dedicated his life to that effort-heading 'a private, nonpartisan, non-profit organization dedicated to the study of significant aspects of contemporary political finance.'

"And that meant almost every waking moment. It included constantly making notes, tearing out articles, and quickly jotting down new facts and figures to add to the historical record or trend analysis of political spending. And that might have been in the midst of almost anything else- such as a conversation, dinner, or on a phone call.

"In his 1976 book he acknowledged 'the encouragement and forbearance of my wife Nancy, and the good cheers of my children Michael, Andrew and Kenneth.' Forbearance is probably the key word here. How kids can grow up around a dinner table talking of fat cats, independent expenditures, soft money, and bundling, is beyond me (even though I inflicted similar pain on my sons). However they survived and appear to be relatively normal.

"Herb also tried to say thank you using the dedications in his own booksthe ultimate product. His Financing the 1960 Election, the first of his books on the presidential races, was dedicated 'To my wife Nancy, whose devotion to my work is exceeded only by her devotion to her family.' And the three editions of his college guide, Financing Politics, are dedicated 'To Nancy, Michael, Andrew and Kenneth.'

"I think the driving dynamic inside Herb was that he had toiled by himself and dug for and found new information that no one else had-and he wanted to get it out to the public.

"That was hard. Financial figures are not the easiest to understand or write about. One usually loses the reader with phrases like, 'Total individual contributions, less un-itemized, and excluding transfers and loans, equals itemized contributions for the period, excluding debts owed.'

"Herb was well aware of this and received valuable guidance from Teddy White. Herb's 1984 book was dedicated: 'To the memory of Theodore H. White, the unexcelled storyteller of American Politics, and for 16 years a dedicated trustee of the Citizens' Research Foundation.'

"Herb also knew that the media was a valuable and necessary part of educating the public. Over the years he worked with reporters and regularly wrote op-ed articles and background pieces about money in politics.

"He also used news articles to help build the base of knowledge. In many cases politicians and party leaders were not forthcoming with inside information on their finances, and reporters had to dig them out with interviews. Herb built all this into his books. For example, his book on the 1976 election was his longest volume and included 1,455 footnotes, many from news articles and interviews.

"Herb's books and publications have always been and still are of value to historians, political scientists, candidates, politicians, legislators, lawyers, and election practitioners.

"In the 1970s and 80s as more states established campaign finance and ethics commissions, early administrators, commissioners, and staff used Herb's books to understand why they were created and what their purpose should be. Herb continued to help state and local agencies, especially New Jersey, New York City, Illinois, California, and Maryland. In 2004 the Council on Governmental Ethics Laws awarded him its highest honor.

"Of course, some people had different points of view from Herb, and some were very strong personalities-but Herb was equally strong minded. And it didn't matter which party you were from, what side of Capitol Hill you were on, he would give you his straight opinion.

"His presence also made politicians, fundraisers, and others think twice about exaggerating or altering the facts. If they were making a speech or presentation that mentioned their best points and maybe omitted a few problem areas, they knew Herb would ask a question to set the record straight in the end - and also plug his latest book. Not that campaign finance books ever made much money.

"Even presidential treasurers and fund raising chairmen relied on him for his information. They would provide him inside data and he would write it up three years later, along with every other campaign. After the election he would hold a forum to talk over what really 
happened and what changes might be recommended.

"Students also benefited from Herb's efforts; countless numbers are now carrying on his research and analysis. In 2002, the University of Southern California awarded him its Distinguished Emeritus Award for his 20-year tenure at the university and 'his seminal scholarship, dedication to teaching and leadership in the academic community.'

"And he did all that without a computer. Herb liked the old joke about campaign finance reporting. He claimed he would do a sequel to Erica Jong's book, Fear of Flying, but would call it 'Fear of Filing.' Perhaps he should have called it 'Fear of the Computer.'

"Actually Gloria Cornette, the assistant director of the Citizens' Research Foundation, was his computer. He thanked her in every book, since she was the only one who could organize his work and get him to a deadline on time. How she did it I don't know. Even this weekend she is seeing to every detail and final arrangement.

"Herbert E. Alexander was my mentor and my friend. I will miss him very much and I think others in the field will long remember his contributions to our society and its democratic process. To his sons and their families, and Bobbie, our prayers are with you."

"Herb stayed interested in political money his entire life. Two months ago we were talking about the 2008 presidential race. He was current on each morning's news and breaking stories. I keep expecting a call from him, asking for a copy of Clinton's tax returns or Obama's Rezko donations or McCain's bank loan papers. He never stopped trying to piece together the puzzle of money in politics."

Many of us would second Kent Cooper's remarks.

Michael J. Malbin University at Albany, SUNY The Campaign Finance Institute

\section{Merle Kling}

Merle Kling, whose entire academic career was spent in association with Washington University in St. Louis, died on April 8, 2008, at the age of 89. Born in Poland, Merle came to St. Louis at the age of two, attended public schools there, majored in political science at Washington University and, following military service during World War II, returned to complete his doctorate and join the faculty. He quickly acquired a reputation as an outstanding teacher and a person of wise judgment on academic matters. In 1966 he became dean of the faculty and was later named provost, the University's chief academic officer. He retired in 1983.

Merle set a very high intellectual standard for himself. Although he wrote a good deal on comparative politics, mainly on Soviet and Latin American matters, he published relatively little of it: two books and a few articles, of modest professional impact. Nonetheless, he gained considerable reputation among political scientists who came to know him for his wide-ranging intelligence and critical capacity. In 1965, Merle was named editor of the Midwest Journal of Political Science, but resigned when he became dean of the Washington University Faculty of Arts and Sciences. He was elected president of the Midwest Political Science Association in 1968.

As a classroom teacher, Merle had few equals. He believed strongly that political scientists should ground their arguments in empirical data and he would fill blackboards with information so structured that students were virtually compelled, for themselves, to reach the conclusions he thought appropriate. After he became dean, he was known on occasion to lead the faculty with similar pedagogical brilliance. Indeed, few scholars could match Merle's skill in designing analyses so that students not only learned the substantive material of his courses, but came to appreciate the process of close analysis.

Merle's lengthy career at Washington University coincided with the university's rise from an institution of reasonably good quality with a strong medical school, but a mainly local or regional reputation, to one of major national stature with high rankings in many fields. His presence in the department of political science was an important factor in the rapid growth of its reputation during the 1960s, and in his several administrative capacities Merle's initiatives led to major programmatic developments throughout the university. Notable among these developments was the Writers Program, centered on the English department, which brought distinguished poets and novelists to the faculty and greatly enhanced the university as a place intellectual vigor and breadth. During the period of campus unrest associated with the war in Vietnam, Merle's good sense and firm convictions helped greatly to bring the university through with a minimum of scars or lasting bitterness.

Merle was a person of exceptional intellectual range. He was enormously well read, especially in modern fiction, and it was thus highly appropriate that upon his retirement, the university established the Merle Kling Professorship in
Modern Letters. He loved to talk about books and writers, often finding instructive connections between the world of the novel and the concerns of political scientists. In the late 1950s, when the writings of C.P. Snow were much in vogue, Merle was particularly enthusiastic about them and published a lengthy essay in the Yale Law Journal analyzing Snow's The Masters, a novel about academic politics.

Merle sometimes seemed almost reclusive, a bit reluctant to let himself go, to expose his thoughts to critical review or venture into uncharted territory. In many ways he was exceptionally local in his experience. Much of what he accomplished he did behind the scenes, screened from the scrutiny of all but a few colleagues or associates. At the same time, however, he was a person with wide acquaintance in the St. Louis civic community where, as among academics, he enjoyed a deserved reputation for wisdom and good judgment. Merle had a lighter side as well. He played a shrewd game of poker, delighted in the theater, enjoyed the Cardinals and an occasional visit to the race track, and could often be seen in the city's better restaurants.

After retirement, Merle enlarged upon these activities, traveling extensively, especially to take in plays in New York and London. He became involved in local politics to some extent and served two years in the appointive position of St. Louis city register. He even left the St. Louis area briefly to serve as interim president of Merce College in Dobbs Ferry, New York.

William H. Danforth, chancellor of Washington University from 1971 to 1995, with whom Merle worked as provost, expressed the essence of Merle's achievement exceptionally well: "In every role, his insights, his clarity of mind, and his wisdom guided his colleagues and students. His balance and good sense protected both academic freedom and academic quality through the late 1960s to the early '70s, and kept Washington University a humane and decent place. More than any other person, he taught me what a university is and how we could all join in making it better."

Robert Blackburn, John Kautsky,

Victor T. Le Vine, and Robert Salisbury Professors Emeriti

Washington University in St. Louis

\section{Eleanor Main}

The faculty and students of Emory University mourn the passing of Eleanor Catherine Main, who served the university as a teacher and administrator for 